\title{
The Course of Anxiety and Depression in Patients with Breast Cancer and Gynaecological Cancer
}

\author{
Reinhold Schwarz ${ }^{\mathrm{a}} \quad$ Oliver Krauss $^{\mathrm{a}} \quad$ Michael Höckel $^{\mathrm{b}} \quad$ Alexandra Meyer $^{\mathrm{b}} \quad$ Markus Zenger $^{\mathrm{c}}$ \\ Andreas Hinz ${ }^{\mathrm{C}}$ \\ a Department of Social Medicine, \\ ${ }^{b}$ Department of Obstetrics and Gynaecology, \\ ${ }^{c}$ Department of Medical Psychology and Medical Sociology, University of Leipzig, Germany
}

\section{Key Words}

Anxiety - Breast cancer - Depression .

Longitudinal study · Psychological distress

\section{Summary}

Background/Aims: The aim of this study was to assess the course of anxiety and depression in cancer patients over time and to detect determinants of the changes in the scores. Patients and Method: Women with breast cancer and gynaecological cancer $(n=367)$ were tested at the beginning (T1) and at the end (T2) of treatment in the hospital, 6 months later (T3), and 12 months later (T4), using the Hospital Anxiety and Depression Scale (HADS). Results: Anxiety and depression were highest at the start of the stay in the hospital. More than half of the women are at least doubtful cases in at least one of the two HADS dimensions. The mean scores declined from T1 to T4. After 1 year, depression scores are similar to those of the general population, while anxiety scores remain elevated. The decline of the HADS scores depends on treatment, time since diagnosis, and education. Conclusions: Women receiving radio- or chemotherapy (compared with surgery only), with a long time since diagnosis, and with a low educational level are at high risk of maintaining high anxiety and depression scores over time.

\section{Introduction}

Breast cancer is responsible for about $27 \%$ of all new cancer cases among women in Europe [1,2]. Although the general prognosis is relatively good with estimated 5-year survival

\author{
Schlüsselwörter \\ Angst - Depressivität · Brustkrebs · Längsschnittstudie · \\ Psychische Belastung
}

\section{Zusammenfassung}

Hintergrund: Ziel der Studie ist die Einschätzung von Angst und Depressivität bei Krebspatientinnen im Zeitverlauf sowie die Ermittlung von Determinanten dieser psychischen Faktoren. Patientinnen und Methode: Frauen mit Brustkrebs und gynäkologischen Tumoren ( $\mathrm{n}=$ 367) wurden zu Beginn (T1) und am Ende (T2) der Krankenhausbehandlung, 6 Monate später (T3) und 12 Monate später (T4) mit der Hospital Anxiety and Depression Scale (HADS) getestet. Ergebnisse: Angst und Depressivität waren zu Beginn des Krankenhausaufenthalts am höchsten. Über die Hälfte der Frauen überschritten den Schwellenwert für zumindest fragliche Fälle in mindestens einer der beiden Dimensionen. Nach einem Jahr waren die Depressivitätswerte denen der Allgemeinbevölkerung angeglichen, wogegen die Angstwerte erhöht blieben. Schlussfolgerung: Für Frauen mit Strahlen- oder Chemotherapie, mit einer langen Zeit seit Diagnosestellung und mit niedrigem Bildungsstand besteht ein erhöhtes Risiko, dass die psychische Belastung über einen langen Zeitraum bestehen bleibt.

\begin{tabular}{ll}
\hline KARGER & @ 2008 S. Karger GmbH, Freiburg \\
Fax +49 7614520714 & Accessible online at: \\
Information@Karger.de & www.karger.com/brc \\
www.karger.com &
\end{tabular}


Table 1. Demographic and disease characteristics of the sample in $\mathrm{T} 1$

\begin{tabular}{|c|c|c|c|c|c|c|}
\hline & \multicolumn{2}{|c|}{$\begin{array}{l}\text { Mamma } \\
\text { carcinoma } \\
\mathrm{n}=174\end{array}$} & \multicolumn{2}{|c|}{$\begin{array}{l}\text { Gynaecol. } \\
\text { carcinoma } \\
\mathrm{n}=193\end{array}$} & \multicolumn{2}{|c|}{$\begin{array}{l}\text { Total sample } \\
\mathrm{n}=367\end{array}$} \\
\hline & $\mathrm{n}$ & $\%$ & $\mathrm{n}$ & $\%$ & $\mathrm{n}$ & $\%$ \\
\hline Age mean (SD), years & 58.7 & $(12.1)$ & 55.7 & $(14.8)$ & 57.1 & $(13.6)$ \\
\hline Age range, years & $25-87$ & & $25-86$ & & $25-87$ & \\
\hline \multicolumn{7}{|l|}{ Age group } \\
\hline$\leq 40$ years & 10 & 5.7 & 38 & 19.7 & 48 & 13.1 \\
\hline $41-50$ years & 39 & 22.4 & 40 & 20.7 & 79 & 21.5 \\
\hline $51-60$ years & 48 & 27.6 & 33 & 17.1 & 81 & 22.1 \\
\hline $61-70$ years & 47 & 27.0 & 44 & 22.8 & 91 & 24.8 \\
\hline$\geq 71$ years & 30 & 17.2 & 38 & 19.7 & 68 & 18.5 \\
\hline \multicolumn{7}{|l|}{ Treatment } \\
\hline Surgery & 110 & 63.2 & 82 & 42.5 & 192 & 52.3 \\
\hline Chemotherapy only & 5 & 2.9 & 18 & 9.3 & 23 & 6.3 \\
\hline Radiotherapy only & 39 & 22.4 & 30 & 15.5 & 69 & 18.8 \\
\hline Radio- and chemotherapy only & 5 & 2.9 & 26 & 13.5 & 31 & 8.4 \\
\hline Others & 15 & 8.6 & 37 & 19.2 & 52 & 14.2 \\
\hline \multicolumn{7}{|l|}{ Reason of treatment } \\
\hline Primary tumour & 127 & 77.0 & 148 & 78.3 & 275 & 77.7 \\
\hline Relapse of primary tumour & 7 & 4.2 & 23 & 12.2 & 30 & 8.5 \\
\hline Metastases & 20 & 12.1 & 10 & 5.3 & 30 & 8.5 \\
\hline Secondary tumour & 11 & 6.7 & 8 & 4.2 & 19 & 5.4 \\
\hline \multicolumn{7}{|l|}{ Time since diagnosis } \\
\hline$\leq 1$ month & 95 & 54.9 & 67 & 35.6 & 162 & 44.9 \\
\hline$>1$ month,$\leq 6$ months & 35 & 20.2 & 81 & 43.1 & 116 & 32.1 \\
\hline$>6$ months & 43 & 24.9 & 40 & 21.3 & 83 & 23.0 \\
\hline \multicolumn{7}{|l|}{ Tumour stage } \\
\hline I & 65 & 48.5 & 64 & 50.8 & 129 & 49.6 \\
\hline II & 40 & 29.9 & 25 & 19.8 & 65 & 25.0 \\
\hline III & 20 & 14.9 & 28 & 22.2 & 48 & 18.5 \\
\hline IV & 9 & 6.7 & 9 & 7.1 & 18 & 6.9 \\
\hline
\end{tabular}

anxiety and depression. Several investigations have shown that these HADS scores are elevated in cancer patients and that there are changes in these parameters over time, indicating that adaptation processes take place.

The general outcome is that depression and anxiety are highest shortly after the diagnosis and that they diminish during the therapy and the time thereafter [5-8]. When the treatment of breast cancer patients was successful and the perceived prognosis is good, anxiety and depression can reach the level of the general population [9-11].

While most of the examinations detect reductions in psychological distress over time, this is not always the case. Fulton et al. [11] tested women with metastatic breast cancer eight times with intervals of 1 week. The mean scores remained relatively unchanged. Other longitudinal studies $[12,13]$ also failed to detect a general decline of emotional distress. The differing results may be due to differences in tumour stage, treatment, and other factors like history of the disease or physician-related factors [14]. A further problem is that the sample sizes of the longitudinal studies are often very small. Drop-out processes reduce the sample sizes and make the results difficult to interpret. HADS values can also vary depending on the country. For example, Japanese mean scores are generally very low $[15,16]$. Therefore, it is preferable to have control groups from the same country, which are furthermore representative of the general population [17].

The aims of the present study are as follows:

- assessment of anxiety and depression in breast cancer patients and patients with gynaecological cancer at different points of time in the course of the treatment,

- comparison of these values with those derived from the general population,

- detection of sociodemographic and illness-related conditions that account for differences in the courses of the psychological variables.

\section{Patients and Methods}

Patients

The study comprises women who were treated at the Leipzig University Hospital or at the municipal hospital St. Georg, Leipzig, Germany, between 2002 and 2004, with the diagnosis breast cancer or gynaecological cancer. Further inclusion criteria were: age 18 years and above, sufficient 
Anxiety Mean Scores

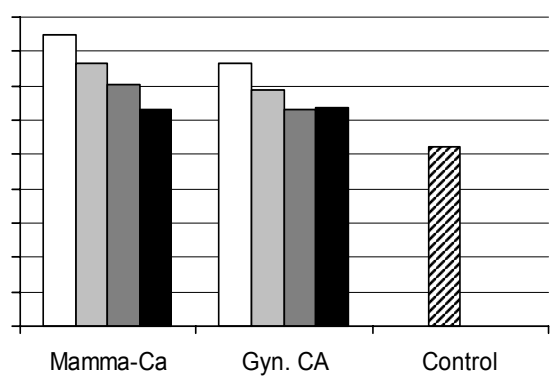

$\square \mathrm{T} 1 \square \mathrm{T} 2 \square \mathrm{T} 3 \square \mathrm{T} 4$
Depression Mean Scores

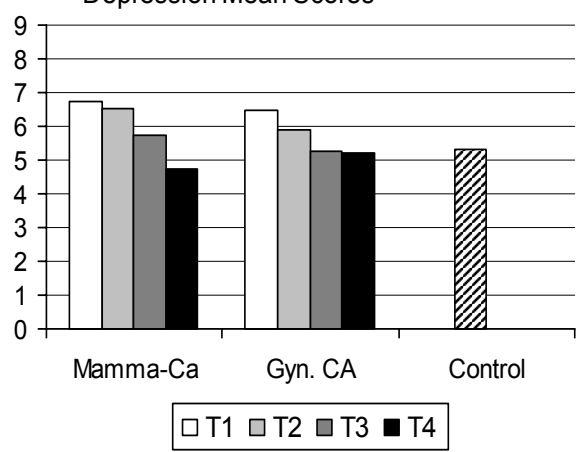

Fig. 1. Mean HADS scores.

\section{Results} guage. Eligible patients were invited to complete several questionnaires, including the HADS. Furthermore, several sociodemographic features such as marital status and education were registered. The cancer registry (Tumorzentrum Leipzig) provided information on cancer stage, treatment, and time since diagnosis. The women were tested four times: (T1) at the beginning of the stay in the hospital, (T2) before discharge, (T3) 6 months after discharge, and (T4) 12 months after discharge. While at T1 and $\mathrm{T} 2$ the questionnaires were administered in the hospital, the questionnaires for $\mathrm{T} 3$ and $\mathrm{T} 4$ were provided by mail. Complete data sets at T1 were available for 367 women (table 1 ). These women represented $42 \%$ of those qualified to take part in the study ( $\mathrm{n}=879$; mean age: 60.2 years $)$ according to the tumour registry. Reasons for non-participation were: current treatment, relocation or discharge, bad physical or mental state, and refusal. The sample comprised the following cancer sites: breast $(n=174)$, cervix $(n=98)$, ovaries $(n=38)$, endometrium $(n=32)$, vulva/vagina $(\mathrm{n}=13)$ and uterus $(\mathrm{n}=12)$. Informed consent was obtained from all participants. The study was approved by the Ethics Committee of the Leipzig University.

\section{Control Group}

The control group was taken from a survey of the general German population [18]. This sample can be assumed to be representative of German people living in private houses. Since the mean age of the women in the original general population sample was lower $(M=49.1$ years $)$ than that of the patients, the control group was restricted to women of 35 years and above. This yielded 880 women with a mean age of 56.0 years $(\mathrm{SD}=13.9)$, which is very similar to that of the patients.

\section{The HADS}

The HADS [4] is a 14-item screening instrument with 7 anxiety and 7 depression items. It has been widely used in hospitals to screen for psychological disorders. There are four answer alternatives for each item, scored with $0-3$. The sum scores are therefore in the range from 0 to 21 . Persons with scores below 8 are called no cases, $8-10$ borderline cases, and 11 and above definite cases. The HADS proved to be able to detect cases of mental disease with sufficient accuracy $[19,20]$. The psychometric properties of the HADS have been extensively studied [21-23].

\section{Statistics}

Comparisons between groups of patients were conducted with t-tests. The significance level (two-tailed) was set to 0.05 .

\section{Anxiety and Depression at Different Points in Time}

Mean HADS scores for T1 to T4 are illustrated in figure 1 for both subgroups. Anxiety and depression diminish from T1 to T4. The figures for the combined sample are given in table 2 . Compared with the general population, anxiety is generally elevated, for all points in time. Elevated depression scores are only found at $\mathrm{T} 1$ and $\mathrm{T} 2$. The percentages of women who were at least doubtful cases in at least one of the two HADS dimensions were as follows: $60.8 \%$ (T1), $50.9 \%$ (T2), $41.6 \%$ (T3), and $43.8 \%$ (T4). In the general population, $37.8 \%(326$ out of 880 women) belonged to this category.

Paired t-tests between two points in time (with those women who took part in the two examinations) resulted in significant $(\mathrm{p}=0.05)$ mean score differences for anxiety (T1:T2; T1:T3; T1:T4; T2:T3) and for depression (T1:T3; T1:T4; T2:T4).

In order to detect the determinants for the reduction of anxiety and depression in more detail, we restricted the analysis to the comparison between T1 (beginning of the stay in hospital) and T3 (6 months after discharge) because the sample size was highest for this pair of time points $(n=228)$.

Both subgroups (breast cancer and gynaecological cancer) are analysed together in table 3 . The reduction of anxiety (diff $=$ 1.69) was more pronounced than that of depression (diff = $0.65)$. Not all women followed this trend. Concerning anxiety, $64.0 \%$ of the women showed a reduced level, $9.6 \%$ remained constant (equal score at T1 and T3), and 26.3\% showed an enhancement of anxiety during the stay in the hospital. The corresponding values for depression are $53.9 \%$ (reduction), $13.6 \%$ (constant), and $32.5 \%$ (enlargement).

Table 3 reports on factors contributing to the changes in psychological distress. The mean reductions of anxiety and depression from $\mathrm{T} 1$ to $\mathrm{T} 3$ were highest among patients with surgery only compared to women receiving radio- or chemotherapy, for women with a short time since diagnosis, and for women with a high level of education. The corresponding group differences were statistically significant (table 3). 
Table 2. Mean scores, standard deviations, and proportions of cases, $\mathrm{T} 1$ to $\mathrm{T} 4$
Table 3. HADS mean scores and difference scores (T1 - T3) for patients with valid data both at $\mathrm{T} 1$ and $\mathrm{T}$

\begin{tabular}{|c|c|c|c|c|c|c|c|c|c|c|c|}
\hline \multirow[b]{3}{*}{ Time } & & \multicolumn{8}{|c|}{ Cancer patients } & \multicolumn{2}{|c|}{ General population } \\
\hline & & \multicolumn{4}{|c|}{ Anxiety } & \multicolumn{4}{|c|}{ Depression } & \multirow[t]{2}{*}{ Anxiety } & \multirow[t]{2}{*}{ Depression } \\
\hline & & $\mathrm{T} 1$ & $\mathrm{~T} 2$ & $\mathrm{~T} 3$ & $\mathrm{~T} 4$ & $\mathrm{~T} 1$ & $\mathrm{~T} 2$ & $\mathrm{~T} 3$ & $\mathrm{~T} 4$ & & \\
\hline $\mathrm{n}$ & & 367 & 269 & 308 & 185 & 367 & 269 & 308 & 185 & 880 & 880 \\
\hline Mean & & 8.16 & 7.33 & 6.59 & 6.45 & 6.59 & 6.41 & 5.56 & 5.14 & 5.25 & 5.34 \\
\hline (SD) & & $(4.37)$ & $(4.16)$ & $(3.93)$ & $(3.90)$ & $(4.56)$ & $(4.48)$ & $(4.22)$ & $(4.07)$ & $(3.41)$ & $(3.93)$ \\
\hline No cases $(0-7)$ & $\begin{array}{l}\mathrm{n} \\
(\%)\end{array}$ & $\begin{array}{l}171 \\
(46.6)\end{array}$ & $\begin{array}{l}151 \\
(56.1)\end{array}$ & $\begin{array}{l}197 \\
(64.0)\end{array}$ & $\begin{array}{l}116 \\
(62.7)\end{array}$ & $\begin{array}{l}226 \\
(61.6)\end{array}$ & $\begin{array}{l}173 \\
(64.3)\end{array}$ & $\begin{array}{l}230 \\
(74.7)\end{array}$ & $\begin{array}{l}141 \\
(76.2)\end{array}$ & $\begin{array}{l}667 \\
(75.8)\end{array}$ & $\begin{array}{l}634 \\
(72.0)\end{array}$ \\
\hline Doubtful cases $(8-10)$ & $\begin{array}{l}\mathrm{n} \\
(\%)\end{array}$ & $\begin{array}{l}93 \\
(25.3)\end{array}$ & $\begin{array}{l}56 \\
(20.8)\end{array}$ & $\begin{array}{l}63 \\
(20.5)\end{array}$ & $\begin{array}{l}44 \\
(23.8)\end{array}$ & $\begin{array}{l}69 \\
(18.8)\end{array}$ & $\begin{array}{l}45 \\
(16.7)\end{array}$ & $\begin{array}{l}39 \\
(12.7)\end{array}$ & $\begin{array}{l}22 \\
(11.9)\end{array}$ & $\begin{array}{l}141 \\
(16.0)\end{array}$ & $\begin{array}{l}146 \\
(16.6)\end{array}$ \\
\hline Cases $(>10)$ & $\begin{array}{l}\mathrm{n} \\
(\%)\end{array}$ & $\begin{array}{l}103 \\
(28.1)\end{array}$ & $\begin{array}{l}62 \\
(23.0)\end{array}$ & $\begin{array}{l}48 \\
(15.6)\end{array}$ & $\begin{array}{l}25 \\
(13.5)\end{array}$ & $\begin{array}{l}72 \\
(19.6)\end{array}$ & $\begin{array}{l}51 \\
(19.0)\end{array}$ & $\begin{array}{l}39 \\
(12.7)\end{array}$ & $\begin{array}{l}22 \\
(11.9)\end{array}$ & $\begin{array}{l}72 \\
(8.2)\end{array}$ & $\begin{array}{l}100 \\
(11.4)\end{array}$ \\
\hline
\end{tabular}

T1: Admission to hospital; T2: discharge; T3: 6 months after discharge; T4: 12 months after discharge.

\begin{tabular}{|c|c|c|c|c|c|c|c|c|c|c|}
\hline & & \multirow[b]{2}{*}{$\mathrm{n}$} & \multicolumn{4}{|c|}{ Anxiety } & \multicolumn{4}{|c|}{ Depression } \\
\hline & & & $\mathrm{T} 1$ & $\mathrm{~T} 3$ & Diff & $\mathrm{t}$-Test ${ }^{\mathrm{a}}$ & $\mathrm{T} 1$ & $\mathrm{~T} 3$ & Diff & t-Test ${ }^{\mathrm{a}}$ \\
\hline Total sample & & 228 & $\begin{array}{l}8.36 \\
(4.46)\end{array}$ & $\begin{array}{l}6.67 \\
(4.09)\end{array}$ & 1.69 & & $\begin{array}{c}6.16 \\
4.45\end{array}$ & $\begin{array}{l}5.51 \\
4.37\end{array}$ & 0.65 & \\
\hline \multicolumn{11}{|l|}{ Age } \\
\hline$\leq 60$ years & $\begin{array}{l}\text { M } \\
(\mathrm{SD})\end{array}$ & 140 & $\begin{array}{l}8.74 \\
(4.60)\end{array}$ & $\begin{array}{l}6.84 \\
(4.04)\end{array}$ & $\begin{array}{l}1.90 \\
(4.17)\end{array}$ & $\begin{array}{l}\mathrm{t}=0.97 \\
\text { n.s. }\end{array}$ & $\begin{array}{l}5.96 \\
(4.67)\end{array}$ & $\begin{array}{l}5.19 \\
(4.37)\end{array}$ & $\begin{array}{l}0.76 \\
(4.31)\end{array}$ & $\begin{array}{l}\mathrm{t}=0.54 \\
\text { n.s. }\end{array}$ \\
\hline$>60$ years & $\begin{array}{l}\mathrm{M} \\
(\mathrm{SD})\end{array}$ & 88 & $\begin{array}{l}7.76 \\
(4.19)\end{array}$ & $\begin{array}{l}6.40 \\
(4.13)\end{array}$ & $\begin{array}{l}1.36 \\
(3.95)\end{array}$ & & $\begin{array}{l}6.48 \\
(4.07)\end{array}$ & $\begin{array}{l}6.02 \\
(4.34)\end{array}$ & $\begin{array}{l}0.45 \\
(4.04)\end{array}$ & \\
\hline \multicolumn{11}{|l|}{ Partnership } \\
\hline without partner & $\begin{array}{l}\mathrm{M} \\
(\mathrm{SD})\end{array}$ & 67 & $\begin{array}{l}7.97 \\
(4.64)\end{array}$ & $\begin{array}{l}6.70 \\
(4.50)\end{array}$ & $\begin{array}{l}1.27 \\
(4.63)\end{array}$ & $\begin{array}{l}\mathrm{t}=1.14 \\
\text { n.s. }\end{array}$ & $\begin{array}{l}6.88 \\
(4.58)\end{array}$ & $\begin{array}{l}6.42 \\
(4.90)\end{array}$ & $\begin{array}{l}0.46 \\
(3.81)\end{array}$ & $\begin{array}{l}\mathrm{t}=0.45 \\
\text { n.s. }\end{array}$ \\
\hline with partner & $\begin{array}{l}\mathrm{M} \\
(\mathrm{SD})\end{array}$ & 157 & $\begin{array}{l}8.53 \\
(4.43)\end{array}$ & $\begin{array}{l}6.58 \\
(3.89)\end{array}$ & $\begin{array}{l}1.95 \\
(3.83)\end{array}$ & & $\begin{array}{l}5.80 \\
(4.41)\end{array}$ & $\begin{array}{l}5.06 \\
4.05)\end{array}$ & $\begin{array}{l}0.74 \\
(3.93)\end{array}$ & \\
\hline \multicolumn{11}{|l|}{ Education } \\
\hline$\leq 10$ years & $\begin{array}{l}\text { M } \\
(\mathrm{SD})\end{array}$ & 174 & $\begin{array}{l}8.18 \\
(4.56)\end{array}$ & $\begin{array}{l}6.79 \\
(4.04)\end{array}$ & $\begin{array}{l}1.40 \\
(3.87)\end{array}$ & $\begin{array}{l}\mathrm{t}=2.15 \\
*\end{array}$ & $\begin{array}{l}6.08 \\
(4.58)\end{array}$ & $\begin{array}{l}5.73 \\
(4.42)\end{array}$ & $\begin{array}{l}0.35 \\
(4.26)\end{array}$ & $\begin{array}{l}\mathrm{t}=2.06 \\
*\end{array}$ \\
\hline$>10$ years & $\begin{array}{l}\mathrm{M} \\
(\mathrm{SD})\end{array}$ & 50 & $\begin{array}{l}9.14 \\
(3.96)\end{array}$ & $\begin{array}{l}6.34 \\
(4.03)\end{array}$ & $\begin{array}{l}2.80 \\
(4.67)\end{array}$ & & $\begin{array}{l}6.40 \\
(3.71)\end{array}$ & $\begin{array}{l}4.66 \\
(3.65)\end{array}$ & $\begin{array}{l}1.74 \\
(4.01)\end{array}$ & \\
\hline \multicolumn{11}{|l|}{ Tumour stage } \\
\hline I & $\begin{array}{l}\text { M } \\
(\mathrm{SD})\end{array}$ & 96 & $\begin{array}{l}8.36 \\
(4.53)\end{array}$ & $\begin{array}{l}6.47 \\
(4.05)\end{array}$ & $\begin{array}{l}1.90 \\
(4.23)\end{array}$ & $\begin{array}{l}\mathrm{t}=0.66^{\mathrm{b}} \\
\text { n.s. }\end{array}$ & $\begin{array}{l}5.76 \\
(4.27)\end{array}$ & $\begin{array}{l}5.17 \\
(4.12)\end{array}$ & $\begin{array}{l}0.59 \\
(4.04)\end{array}$ & $\begin{array}{l}\mathrm{t}=0.40^{\mathrm{b}} \\
\text { n.s. }\end{array}$ \\
\hline II & $\begin{array}{l}\text { M } \\
(\mathrm{SD})\end{array}$ & 38 & $\begin{array}{l}8.42 \\
(3.71)\end{array}$ & $\begin{array}{l}6.95 \\
(3.78)\end{array}$ & $\begin{array}{l}1.47 \\
(4.08)\end{array}$ & & $\begin{array}{l}6.29 \\
(3.92)\end{array}$ & $\begin{array}{l}5.76 \\
(4.05)\end{array}$ & $\begin{array}{l}0.53 \\
(4.37)\end{array}$ & \\
\hline III & $\begin{array}{l}\mathrm{M} \\
(\mathrm{SD})\end{array}$ & 30 & $\begin{array}{l}7.67 \\
(4.58)\end{array}$ & $\begin{array}{l}6.20 \\
(4.23)\end{array}$ & $\begin{array}{l}1.47 \\
(3.66)\end{array}$ & & $\begin{array}{l}5.67 \\
(4.09)\end{array}$ & $\begin{array}{l}5.57 \\
(4.25)\end{array}$ & $\begin{array}{l}0.10 \\
(3.84)\end{array}$ & \\
\hline IV & $\begin{array}{l}\text { M } \\
(\mathrm{SD})\end{array}$ & 6 & $\begin{array}{l}10.83 \\
(5.91)\end{array}$ & $\begin{array}{l}8.00 \\
(6.20)\end{array}$ & $\begin{array}{l}2.83 \\
(3.13)\end{array}$ & & $\begin{array}{l}9.67 \\
(6.19)\end{array}$ & $\begin{array}{l}8.00 \\
(5.10)\end{array}$ & $\begin{array}{l}1.67 \\
(4.37)\end{array}$ & \\
\hline \multicolumn{11}{|l|}{ Therapy } \\
\hline Surgery only & $\begin{array}{l}\mathrm{M} \\
(\mathrm{SD})\end{array}$ & 134 & $\begin{array}{l}9.04 \\
4.57\end{array}$ & $\begin{array}{l}6.51 \\
3.90\end{array}$ & $\begin{array}{l}2.53 \\
(3.69)\end{array}$ & $\begin{array}{l}\mathrm{t}=3.86 \\
* * *\end{array}$ & $\begin{array}{l}6.46 \\
4.57\end{array}$ & $\begin{array}{l}5.43 \\
4.20\end{array}$ & $\begin{array}{l}1.03 \\
(4.02)\end{array}$ & $\begin{array}{l}\mathrm{t}=2.75 \\
*\end{array}$ \\
\hline $\begin{array}{l}\text { Radio- and/or } \\
\text { chemotherapy }\end{array}$ & $\begin{array}{l}\mathrm{M} \\
(\mathrm{SD})\end{array}$ & 63 & $\begin{array}{l}7.44 \\
4.08\end{array}$ & $\begin{array}{l}7.16 \\
4.29\end{array}$ & $\begin{array}{l}0.28 \\
(4.05)\end{array}$ & & $\begin{array}{l}5.70 \\
3.86\end{array}$ & $\begin{array}{l}6.05 \\
4.38\end{array}$ & $\begin{array}{l}-0.35 \\
(3.97)\end{array}$ & \\
\hline \multicolumn{11}{|l|}{ Time since diagnosis } \\
\hline$\leq 1$ month & $\begin{array}{l}\mathrm{M} \\
(\mathrm{SD})\end{array}$ & 107 & $\begin{array}{l}8.86 \\
4.36\end{array}$ & $\begin{array}{l}6.35 \\
3.82\end{array}$ & $\begin{array}{l}2.51 \\
(3.97)\end{array}$ & $\begin{array}{l}\mathrm{t}=2.85 \\
* *\end{array}$ & $\begin{array}{l}6.37 \\
4.45\end{array}$ & $\begin{array}{l}5.07 \\
3.72\end{array}$ & $\begin{array}{l}1.30 \\
(4.30)\end{array}$ & $\begin{array}{l}\mathrm{t}=2.26 \\
*\end{array}$ \\
\hline$>1$ month & $\begin{array}{l}\mathrm{M} \\
(\mathrm{SD})\end{array}$ & 118 & $\begin{array}{l}7.84 \\
4.52\end{array}$ & $\begin{array}{l}6.86 \\
4.21\end{array}$ & $\begin{array}{l}0.98 \\
(4.07)\end{array}$ & & $\begin{array}{l}5.75 \\
4.24\end{array}$ & $\begin{array}{l}5.70 \\
4.65\end{array}$ & $\begin{array}{l}0.05 \\
(4.08)\end{array}$ & \\
\hline
\end{tabular}

$*: \mathrm{p}<0.05 ; * *: \mathrm{p}<0.01 ; * * *: \mathrm{p}<0.001 ;$ n.s.: not significant.

T1: Admission to hospital; T3: 6 months after discharge.

${ }^{\mathrm{a}}$ Group mean differences between T3 and T1.

${ }^{\mathrm{b}}$ Comparison between stage I and the combined groups of stage II and stage III. 
Separate analyses for both subgroups (breast cancer patients and other gynaecological patients) yielded similar results. However, some of the comparisons of table 3 failed to become statistically significant because of the lower sample sizes.

\section{Discussion}

At the beginning of the stay in the hospital, anxiety and depression scores were high. More than half of the women were at least doubtful cases in at least one of the two HADS dimensions. This number is nearly twice as high as the corresponding number in the (age-matched) general population. This confirms previous findings and indicates the need for screening psychological distress in order to provide adequate psychological support for the women [24].

The severity of the psychological burden generally diminished over time. At the end of the stay in the hospital, HADS anxiety and depression mean scores were significantly lower than before. During further months, the mean scores continued to decrease. While depression scores reached normal values after some months, anxiety scores remained elevated compared with the general population, at least for 1 year. However, a decline of anxiety and depression could not be observed in all women. About one third of the women showed an opposite trend, with increasing values from T1 to T3.

The comparison between several subgroups of the samples provided information about the factors underlying differences in the reduction of anxiety and depression. First of all, patients with surgery had high anxiety scores before surgery and greatest normalisations thereafter. For these women, both cancerrelated and surgery-related factors contributed to anxiety. Women receiving radiotherapy and/or chemotherapy remained roughly constant in their mean anxiety and depression levels. As one could expect, the time since diagnosis also influenced the degree of psychological distress, with higher scores shortly after the first diagnosis. However, among the women with long time intervals between diagnosis and psychological test, there were also women with tumour relapses, which could also have a traumatic influence.

An interesting finding is the influence of education on psychological distress. Women with higher education were more stressed by cancer than women with lower educational levels. However, after several months these differences disappeared. Probably, highly educated women are mentally more occupied by the cancer situation at the beginning, but the adaptation process is more pronounced.

The results of this study can contribute to ameliorate the psychosocial health care which shows a discrepancy between indication and realisation of psychosocial support [25]. High anxiety among cancer patients can be associated with a greater desire for additional examination and treatment [9] and with a greater affinity to alternative or complementary healing techniques [26]. Physicians can contribute to reduce anxiety by talking with the patients extensively enough about all crucial topics, like the severity of the disease and life expectancy.

\section{Limitations}

- Since no initial hypotheses were formulated, the results (especially those of prognostic factors for the HADS reductions) are preliminary and deserve further verification.

- The study comprises cases with different diagnoses and different stages in the disease process. Analyses with more homogeneous samples would contribute to clarify the influence of these factors. However, the aggregation was necessary here in order to get sufficient sample sizes.

\section{References}

1 Ferlay J, Bray F, Pisani P, et al: GLOBOCAN 2000: Cancer incidence, mortality and prevalence worldwide, version 1.0, in: IARC CancerBase No. 5 Lyon, International Agency for Research on Cancer Press, 2001

2 Tyczynski JE, Bray F, Parkin DM: Breast cancer in Europe. Fact sheet, European Network of Cancer Registries ENCR 2002. www.encr.com.fr/breastfactsheets.pdf.

3 Brenner H: Long-term survival rates of cancer patients achieved by the end of the 20th century: A period analysis. Lancet 2002;360:1131-1135.

$\checkmark 4$ Zigmond AS, Snaith RP: The Hospital Anxiety and Depression Scale. Acta Psychiatr Scand 1983; 67:361-370.

5 Jadoulle V, Rokbani L, Ogez D, et al: Coping and adapting to breast cancer: A six-month prospective study. Bull Cancer 2006;93:E67-E72.

6 Bang S-M, Se HP, Hee GK, et al: Changes in quality of life during palliative chemotherapy for solid cancer. Support Care Cancer 2005;13:515-521.
7 Iconomou G, Mega V, Koutras A, Iconomou AV, Kalofonos HP: Prospective assessment of emotional distress, cognitive function, and quality of life in patients with cancer treated with chemotherapy. Cancer 2004:101:404-411.

8 Geinitz H, Zimmermann FB, Thamm R, Keller M, Busch R, Molls M: Fatigue in patients with adjuvant radiation therapy for breast cancer: Long-term follow-up. J Cancer Res Clin Oncol 2004;130:327-333.

$\checkmark 9$ De Bock GH, Bonnema J, Zwaan RE, Van De Velde CJH, Kievit J, Stiggelbout AM: Patient's needs and preferences in routine follow-up after treatment for breast cancer. Br J Cancer 2004;90: 1144-1150.

10 Lampic C, Thurfjell E, Bergh J, Sjoden PO: Shortand long-term anxiety and depression in women recalled after breast cancer screening. Eur J Cancer 2001;37:463-469.

11 Fulton C: The prevalence and detection of psychiatric morbidity in patients with metastatic breast cancer. Eur J Cancer Care 1998;7:232-239.
12 Matsushita T, Matsushima E, Maruyama M: Anxiety and depression of patients with digestive cancer. Psychiatr Clin Neurosci 2005;59:576-583.

13 Lee TS, Kilbreath SL, Refshauge KM, Pendlebury SC, Beith JM, Lee MJ: Quality of life of women treated with radiotherapy for breast cancer. Support Care Cancer 2008;16:399-405.

14 Schofield PE, Butow PN, Thompson JF, Tattersall MHN, Beeney LJ, Dunn SM: Psychological responses of patients receiving a diagnosis of cancer. Ann Oncol 2003;14:48-56.

15 Tsunoda A, Nakao K, Hiratsuka K: Anxiety, depression and quality of life in colorectal cancer patients. Int J Clin Oncol 2005;10:411-417.

16 Akechi T, Okuyama T, Sugawara Y, Shima Y, Furukawa TA: Screening for depression in terminally ill cancer patients in Japan. J Pain Symptom Manage 2006;31:5-12.

17 Osborne RH, Elsworth GR, Sprangers MAG, Oort FJ, Hopper JL: The value of the Hospital Anxiety and Depression Scale (HADS) for comparing women with early onset of breast cancer with population-based reference women. Qual Life Res 2004; 13:191-204. 
18 Hinz A, Kittel J, Karoff M, Schwarz R: Age and sex dependencies of anxiety and depression in cardiologic patients compared with the general population. Online J Psychosoc Med 2004;1:Doc09. www. egms.de/en/journals/psm/2004-1/psm000009.shtml.

19 Love AW, Kissane DW, Bloch S, Clarke DM: Diagnostic efficiency of the Hospital Anxiety and Depression Scale in women with early stage breas cancer. Aust N Z J Psychiatry 2002;36:246-250.

20 Ibbotson T, Maguire P, Selby P, Priestman T, Wallace L: Screening for anxiety and depression in cancer patients: The effects of disease and treatment. Eur J Cancer 1994;30A:37-40.
Bjelland I, Dahl AA, Haug TT, Neckelmann D: The validity of the Hospital Anxiety and Depression Scale. An updated literature review. J Psychosom Res 2002;52:69-77.

22 Crawford JR, Henry JD, Crombie C, Taylor EP: Normative data for the HADS from a large nonclinical sample. Br J Clin Psychol 2001;40:429-434.

23 Stordal E, Bjartveit Kruger M, Dahl NH, Kruger O, Mykletun A, Dahl AA: Depression in relation to age and gender in the general population: the Nord-Trøndelag Health Study (HUNT). Acta Psychiatr Scand 2001;104:210-216.
24 Arving C, Sjöden P-O, Bergh J, et al: Satisfaction, utilisation and perceived benefit of individual psychosocial support for breast cancer patients - A randomised study of nurse versus psychologist intervention. Patient Educ Couns 2006;62:235-243.

25 Neises M, Bitzer J, Ditz S, Keller M, Mehnert A, Wimmer-Puchinger B: Psychoonkologie - spezielle Aspekte bei Brustkrebspatientinnen. Breast Care 2007;2;321-328.

26 Eustachi A: Complementary therapies in breast cancer patients. Breast Care 2007;2:209-216. 